Article

\title{
Investigation of a Novel Ecofriendly Electrolyte-Solvent for Lithium-Ion Batteries with Increased Thermal Stability
}

\author{
Marco Ströbel *D, Larissa Kiefer and Kai Peter Birke \\ Electrical Energy Storage Systems, Institute for Photovoltaics, University of Stuttgart, Pfaffenwaldring 47, \\ 70569 Stuttgart, Germany; st142567@stud.uni-stuttgart.de (L.K.), Peter.Birke@ipv.uni-stuttgart.de (K.P.B.) \\ * Correspondence: Marco.Stroebel@ipv.uni-stuttgart.de
}

\begin{abstract}
This study presents tributyl acetylcitrate (TBAC) as a novel ecofriendly high flash point and high boiling point solvent for electrolytes in lithium-ion batteries. The flash point $\left(T_{\mathrm{FP}}=217^{\circ} \mathrm{C}\right)$ and the boiling point $\left(\mathrm{T}_{\mathrm{BP}}=331^{\circ} \mathrm{C}\right)$ of $\mathrm{TBAC}$ are approximately $200 \mathrm{~K}$ greater than that of conventional linear carbonate components, such as ethyl methyl carbonate (EMC) or diethyl carbonate (DEC). The melting point $\left(T_{\mathrm{MP}}=-80^{\circ} \mathrm{C}\right)$ is more than $100 \mathrm{~K}$ lower than that of ethylene carbonate (EC). Furthermore, TBAC is known as an ecofriendly solvent from other industrial sectors. A life cycle test of a graphite/NCM cell with $1 \mathrm{M}$ lithium hexafluorophosphate $\left(\mathrm{LiPF}_{6}\right)$ in TBAC:EC:EMC:DEC (60:15:5:20 wt) achieved a coulombic efficiency of above $99 \%$ and the remaining capacity resulted in 90 percent after 100 cycles $(C / 4)$ of testing. As a result, TBAC is considered a viable option for improving the thermal stability of lithium-ion batteries.
\end{abstract}

Keywords: ecofriendly electrolyte for lithium-ion batteries; increased thermal stability of electrolytes; enhanced electrolyte safety based on high flash point; tributylacetylcitrate; acetyltributylcitrate

Citation: Ströbel, M.; Kiefer L.; Birke,

K.P. Investigation of a Novel

Ecofriendly Electrolyte-Solvent for Lithium-Ion Batteries with Increased Thermal Stability. Batteries 2021, 7, 72. https://doi.org/10.3390/

batteries7040072

Academic Editor: Catia Arbizzani

Received: 28 July 2021

Accepted: 12 October 2021

Published: 28 October 2021

Publisher's Note: MDPI stays neutral with regard to jurisdictional claims in published maps and institutional affiliations.

Copyright: (c) 2021 by the authors. Licensee MDPI, Basel, Switzerland. This article is an open access article distributed under the terms and conditions of the Creative Commons Attribution (CC BY) license (https:// creativecommons.org/licenses/by/ $4.0 /)$.

\section{Introduction}

Lithium-ion cells are the technological standard for portable devices such as smartphones, notebooks, and electric vehicles, and as a result, they are viewed as a key for the global transition to electro-mobility. In terms of thermal stability, the electrolyte of a lithium-ion cell is considered a critical component, which is responsible for ionic conductivity. The electrolyte is mainly composed of solvents, lithium conducting salts, and various additives [1,2]. The usage of conventional solvents for electrolytes with low boiling points and flash points $\left(T_{\mathrm{FP}}\right)$ like dimethyl carbonate (DMC, $\left.T_{\mathrm{FP}}<20^{\circ} \mathrm{C}[3]\right), \mathrm{EMC}$ $\left(T_{\mathrm{FP}} \approx 22{ }^{\circ} \mathrm{C}[4]\right)$, or $\mathrm{DEC}\left(T_{\mathrm{FP}} \approx 25^{\circ} \mathrm{C}[5]\right)$ bear an increased risk to ignite lithium-ion cells [6-8]. The low boiling point generates high pressure gradients at moderate temperatures $\left(<100^{\circ} \mathrm{C}\right)$, which can lead to the explosion of the cell. The chemical products of burned fluorine-containing electrolytes are highly toxic [9-12]. Therefore, an expensive thermal management system and a massive casing for lithium-ion batteries are required. This heavy casing for battery packs for electric vehicles lowers the gravimetric density of the pack and increases the weight of the vehicles. Increasing the intrinsic thermal stability is a key factor to lower costs for cell protection and increase the gravimetric density of the battery pack. Investigations on new electrolyte formulations have been considered before, for example by using flame retardant additives like organic phosphates [13] or phosphonates [14]. However, using these additives to improve the thermal stability reduces the cell performance [15]. Investigations show that the use of ionic liquids can increase the flash point of electrolytes however, these ionic liquids are linked with high costs [16-19]. Another promising approach is to investigate co-solvents with higher flash points like adiponitrile (ADN, $T_{\mathrm{FP}} \approx 163^{\circ} \mathrm{C}$ [20]) by Isken et al [21]. Co-solvents were able to increase the flash point significantly from $T_{\mathrm{FP}, \mathrm{EC}: \mathrm{DEC}} \approx 36{ }^{\circ} \mathrm{C}$ of the EC:DEC $(3: 7 \mathrm{wt})$ mixture to $T_{\mathrm{FP}, \mathrm{EC}: \mathrm{ADN}} \approx 149^{\circ} \mathrm{C}$ of the EC:ADN $(1: 1 \mathrm{wt})$ mixture. This indicates that it is possible to formulate electrolytes with higher flash points by replacing volatile carbonates. However, 
the melting points (MP) of $\mathrm{EC} T_{\mathrm{MP}, \mathrm{EC}} \approx 36{ }^{\circ} \mathrm{C}$ and $\mathrm{ADN} \mathrm{T}_{\mathrm{MP}, \mathrm{ADN}} \approx 2{ }^{\circ} \mathrm{C}$ are extremely high for low temperature applications. To lower the working temperature applicability $T<0{ }^{\circ} \mathrm{C}$ research has shown many different classes of solvents like sulfones [22,23]. Unfortunately, most of these solvents are ecologically harmful.

Therefore, we investigated tributyl acetylcitrate as a solvent to formulate an electrolyte composition with a high flash point and a wide operating range from very low to high temperature. TBAC has a high flash point of $T_{\mathrm{FP}} \approx 217^{\circ} \mathrm{C}$ [24], its melting point is very low with $T_{\mathrm{MP}} \approx-80^{\circ} \mathrm{C}$ and the boiling point is at $T_{\mathrm{BP}} \approx 330^{\circ} \mathrm{C}$. Another noteworthy advantage of TBAC is that it is ecofriendly [25], nontoxic [26], and therefore safe to handle. For example, it is well known as a plasticizer in the nail polish industry [27].

This study presents tributyl acetylcitrate as a novel solvent for lithium-ion cells. The combination of conventional solvents like EC and DEC with TBAC creates an electrolyte with improved thermal stability.

\section{Materials and Methods}

\subsection{Materials}

Tributyl acetylcitrate (TBAC, purity $>98 \%$ Sigma Aldrich, Germany) was dried over a molecular sieve (mesh size $\approx 0.3 \mathrm{~nm}$ ) inside a glovebox exposed to argon atmosphere over night (moisture content of less than $0.5 \mathrm{ppm}$ ). Figure 1 shows the chemical structure of TBAC [24]. Ethylene carbonate (EC), ethyl methyl carbonate (EMC, purity $>99.9 \%$ ), propylene carbonate ( $\mathrm{PC}$, purity > 99.7\%), diethyl carbonate (DEC, purity $>99.9 \%$ ), lithium tetrafluoroborate $\left(\mathrm{LiBF}_{4}\right.$ purity $>99 \%$, all from Sigma Aldrich), lithium bis(trifluoromethanesulfonyl)imide (LiTFSI, purity $>99 \%$ ), lithium bis(fluorosulfonyl)imide (LiFSI, both fromIOLITEC GmbH, Germany), and lithium hexafluorophosphate ( $\mathrm{LiPF}_{6}$, BASF) were opened in the glovebox and were used as received.

Graphite electrodes ( $3 \mathrm{mAh} / \mathrm{cm}^{2}$, provided by Varta AG) and lithium nickel manganese cobalt oxide electrodes (NCM 622, $1.3 \mathrm{mAh} / \mathrm{cm}^{2}$, provided by Münster Electrochemical Energy Technology) were punched to $18 \mathrm{~mm}$ coins and dried in a vacuum oven (Buechi Labortechnik AG B-585, $p<50$ mbar, $T=120{ }^{\circ} \mathrm{C}$ ). The separator Freudenberg 2190 (thickness $=176 \mu \mathrm{m}$ ) was punched to coins with $21 \mathrm{~mm}$ in diameter and dried in a vacuum oven $\left(p<50 \mathrm{mbar}, T=120^{\circ} \mathrm{C}\right)$.

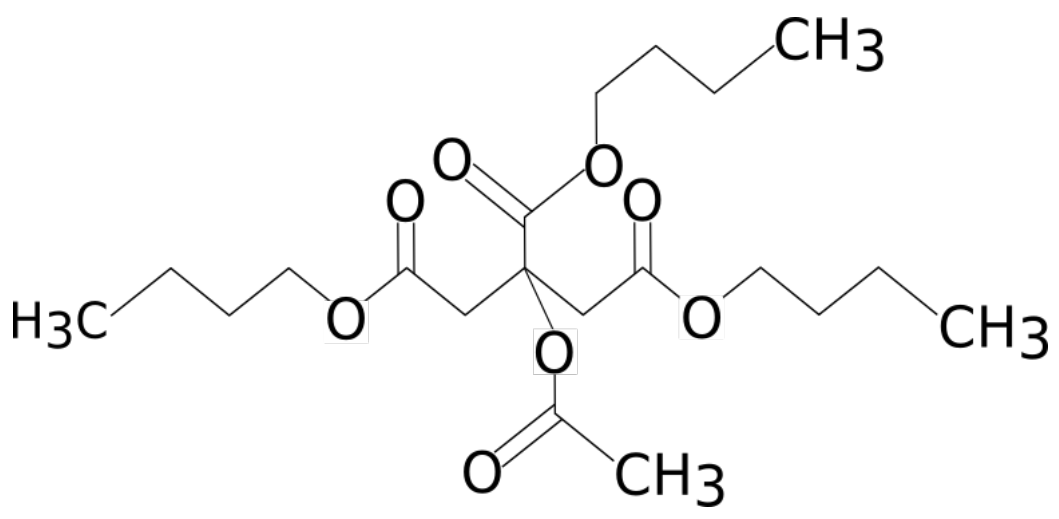

Figure 1. Chemical structure of tributyl acetylcitrate [24].

\subsection{Electrolyte Preparation}

The electrolytes were prepared in an argon-filled glovebox $\left(\mathrm{H}_{2}\right.$ and $\mathrm{O}_{2}$ content lower than $0.5 \mathrm{ppm})$. TBAC was combined with different well-known solvents like EC and EMC. The formulated solvent mixtures and the amount of each solvent (in wt) is shown in Table 1a. Table $1 \mathrm{~b}$ shows the combination of the solvent mixtures and the investigated lithium salts with a salt concentration of $1 \mathrm{M}$. 
Table 1. (a) Formulated solvent-mixtures wt. (b) Investigated combinations of lithium salts and solvent-mixtures (concentration of $1 \mathrm{M}$ ).

(a)

\begin{tabular}{cccccc}
\hline Mixture & TBAC & EC & EMC & PC & DEC \\
\hline F1 & $85 \%$ & $15 \%$ & $0 \%$ & $0 \%$ & $0 \%$ \\
F2 & $80 \%$ & $15 \%$ & $5 \%$ & $0 \%$ & $0 \%$ \\
F3 & $60 \%$ & $15 \%$ & $5 \%$ & $20 \%$ & $0 \%$ \\
F4 & $60 \%$ & $15 \%$ & $5 \%$ & $0 \%$ & $20 \%$ \\
\hline
\end{tabular}

(b)

\begin{tabular}{cllll}
\hline Salt & \multicolumn{3}{l}{ Solvent-Mixtures } \\
\hline LiBF $_{4}$ & & F2 & & \\
LiTFSI $_{\text {LiPF }}$ & F1 & F2 & F3 & F4 \\
LiFSI & & F2 & F3 & F4 \\
\hline
\end{tabular}

\subsection{Cell Preparation}

Cells were assembled as coin cells in PAT-Cell or ECC-Ref cells from EL Cell. For constant current cycling and C-rate tests, cells were assembled with NCM as the working electrode and graphite as the counter electrode. The polypropylene separator (Freudenberg FS2190) was moistened on both sides with a total of $120 \mu \mathrm{L}$ of the selected electrolyte before the electrodes were added. For cyclic voltammetry measurements, two electrode cells were assembled with stainless steel or aluminum as working electrode and stainless steel as counter and reference electrode.

\subsection{Electrochemical Characterization}

All tests were done in a Memmert IPP110 thermal chamber at a constant temperature of $T=25 \pm 0.1^{\circ} \mathrm{C}$. The cell performance was evaluated by cycling tests with constant current charge and discharge with the battery tester CTS from BaSyTec. At the beginning, three preliminary formation cycles were performed at $I=C / 10$ in a potential range from $U=2.5 \mathrm{~V}$ to $U=4.2 \mathrm{~V}$. Subsequently lifecycle tests were performed at $C / 4$.

The cyclic voltammetry measurements were performed with a reference 3000 AE from Gamry. The electrochemical stability was measured by linear sweep voltammetry. The scan rate was set to $1 \mathrm{mVs}^{-1}$, the potential limits were set from $-4.3 \mathrm{~V}$ to $4.3 \mathrm{~V}$ vs. stainless steel.

\section{Results}

Table 2 shows the melting, flash, and boiling point of TBAC, EC, EMC, PC, and DEC. The boiling point as well as the flash point $T_{\mathrm{FP}}=217^{\circ} \mathrm{C}$ of TBAC is almost $200 \mathrm{~K}$ higher than that of EMC and DEC. The melting point is more than $100 \mathrm{~K}$ lower than that of EC. The high boiling point and the high flash point are the main advantages of TBAC as a solvent for lithium-ion batteries. However, during cell preparation, TBAC showed a higher viscosity than the other solvents, which could cause a lower conductivity. Therefore, the solvent-mixtures shown in Table 1 were investigated to find a composition with adequate cycling behavior and a high amount of TBAC.

Table 2. Physical properties of TBAC [24], EC [28], EMC [4], PC [29], and DEC [5]. Symbols used: $T_{\mathrm{MP}}$, melting point; $T_{\mathrm{FP}}$, flash point; $T_{\mathrm{BP}}$, boiling point.

\begin{tabular}{cccc}
\hline & $\boldsymbol{T}_{\mathbf{M P}}\left({ }^{\circ} \mathbf{C}\right)$ & $\boldsymbol{T}_{\mathbf{F P}}\left({ }^{\circ} \mathbf{C}\right)$ & $\boldsymbol{T}_{\mathbf{B P}}\left({ }^{\circ} \mathbf{C}\right)$ \\
\hline TBAC & -80 & 217 & 331 \\
EC & 36 & 143 & 248 \\
EMC & -55 & 23.9 & 101 \\
PC & -49 & 123 & 243 \\
DEC & -43 & 25 & 126 \\
\hline
\end{tabular}


The following discussion is structured by presenting the results for each investigated conducting salt in combination with TBAC-based solvent mixtures from Table 1.

The main focus lies in combining TBAC with LiTFSI since other conducting salts are thermally less stable [30]. However, other possible combinations of salts are presented to give an overview of further possibilities.

\subsection{TBAC Solvent-Mixtures with LiTFSI}

The lithium salt concentration of $1 \mathrm{M}$ LiTFSI seems to be completely dissolvable in F1 = TBAC:EC (85:15 wt). However, in a cell with NCM as positive electrode and graphite as a negative electrode with LiTFSI in F1, the coulombic efficiency of the life cycle test was only about $\eta_{\text {coul }}=80 \%$ and the ionic conductivity limits the current to a maximum of $C / 10$ at $T=25^{\circ} \mathrm{C}$. By adding EMC to the solvent-mixture, the coulombic efficiency increased above $\eta_{\text {coul }}=99 \%$. To increase the life cycle performance, DEC was added to the electrolyte. This resulted in an increase of conductivity that allowed to cycle the cells with C/4. Figure 2 shows the results of the cycling test of a graphite/NCM cell with the electrolyte formulation with $1 \mathrm{M}$ LiTFSI in the solvent mixture F4 = TBAC:EC:EMC:DEC (60:15:5:20 wt) at a C-rate of $C / 4$ at $T=25^{\circ} \mathrm{C}$.

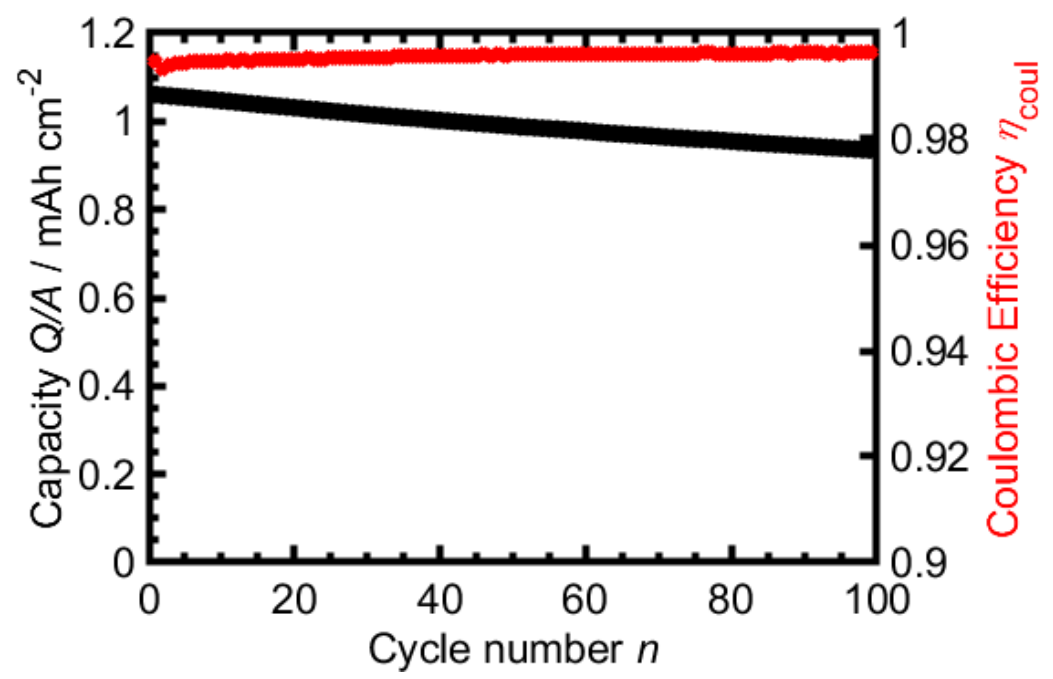

Figure 2. Cycling performance of a graphite/NCM cell with $1 \mathrm{M}$ LiTFSI in TBAC:EC:EMC:DEC (60:15:5:20 wt) electrolyte at $T=25^{\circ} \mathrm{C}$. The cell was charged and discharged at $\mathrm{C}$-rate $\mathrm{C} / 4$.

The coulombic efficiency achieved was $\eta_{\text {coul }}=99.6 \%$. After 100 cycles there was about $88 \%$ of the initial capacity left. Different lithium salt concentrations between $0.8 \mathrm{M}$ and 1.2 $\mathrm{M}$ were investigated. The best cycling performance was achieved with a concentration of $1 \mathrm{M}$. Therefore, all further tests were done with a salt concentration of $1 \mathrm{M}$.

$C$-rate tests were performed to investigate the electrode performance in combination with the novel electrolyte composition for different currents. Figure 3 shows the capacity obtained at different C-rates for a graphite/NCM cell with $1 \mathrm{M}$ LiTFSI in the solventmixture F4. 


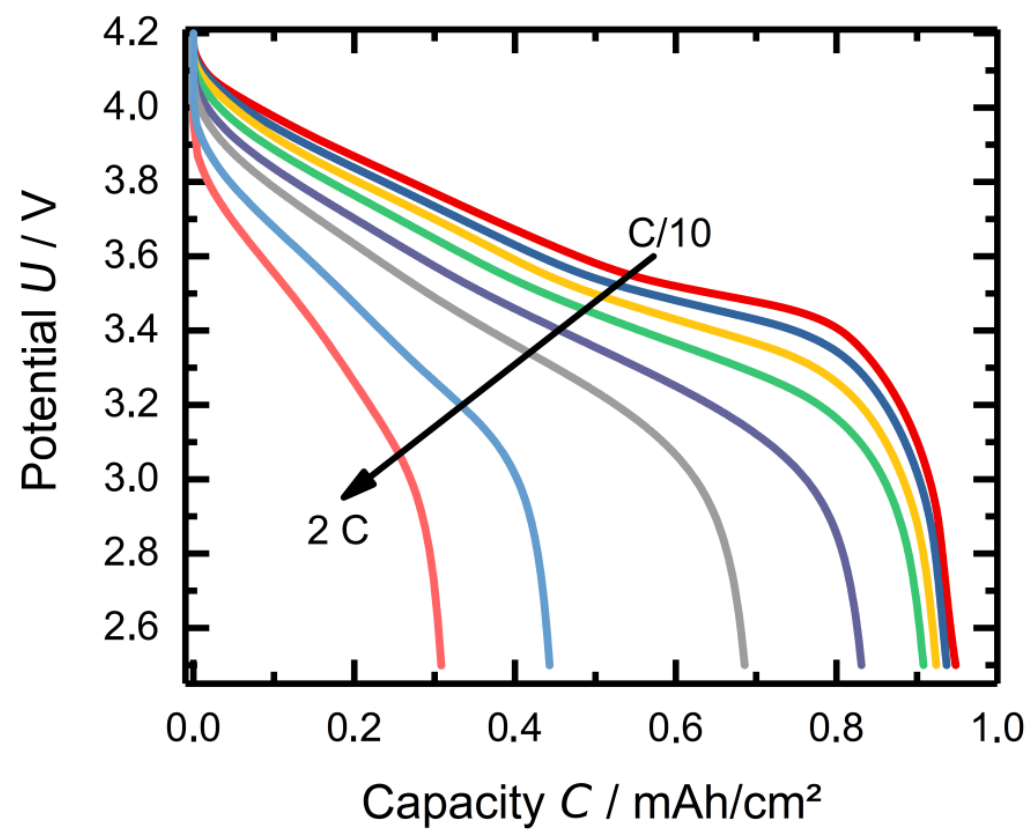

Figure 3. C-rate performance of a graphite/NCM cell with 1 M LiTFSI in TBAC:EC:EMC:DEC (60:15:5:20 wt) electrolyte at $T=25^{\circ} \mathrm{C}$ in the potential range of $2.5-4.2 \mathrm{~V}$.

The applied currents were: $C / 10, C / 5, C / 3, C / 2,0.75 C, 1 C, 1.5 C$, and $2 C$. At a current rate of $1 C$, the usable capacity dropped to $70 \%$ of the initial capacity. Higher $C$-rates decrease the usable capacity significantly.

Figure 4 shows the discharge capacity and the potential profiles at different temperatures between $T=30^{\circ} \mathrm{C}$ and $T=70^{\circ} \mathrm{C}$. Until $60^{\circ} \mathrm{C}$ the voltage profile seems to be nearly independent of temperature. At $70{ }^{\circ} \mathrm{C}$ there was a small drop in voltage observed.

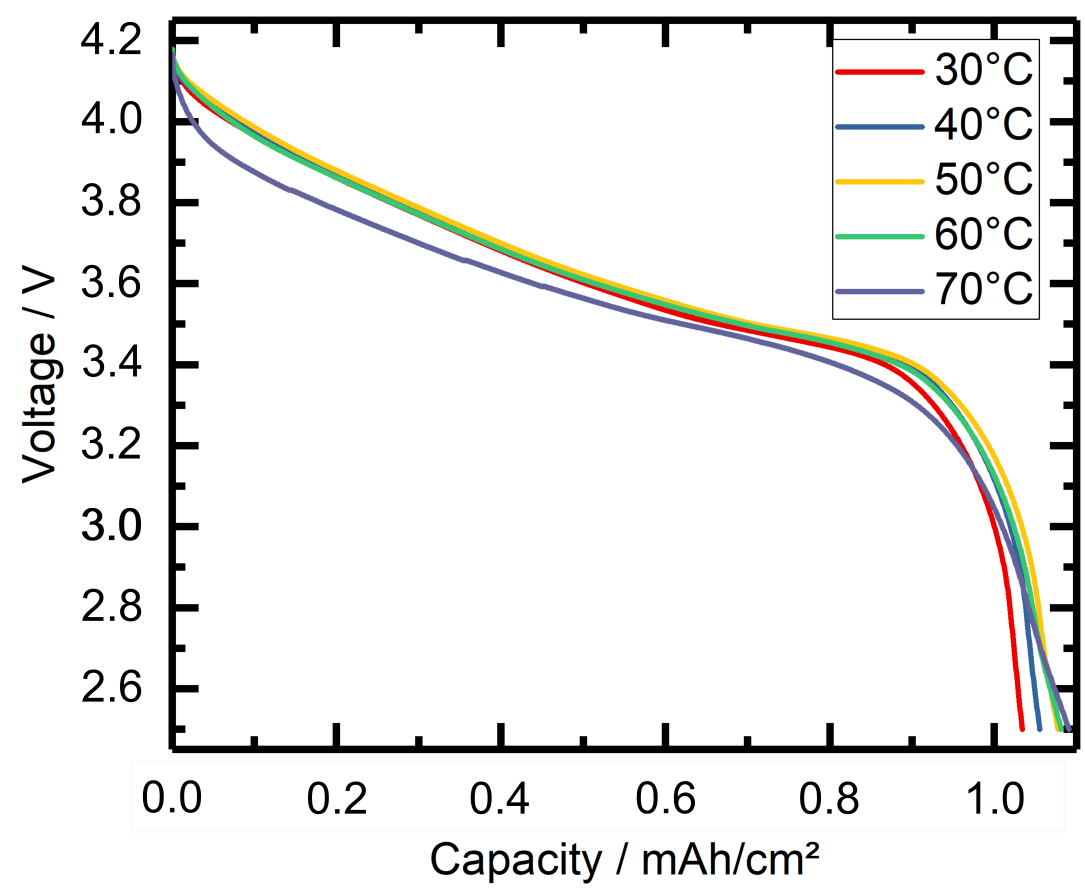

Figure 4. Voltage profiles at different temperatures of a graphite/NCM cell with $1 \mathrm{M}$ LiTFSI in TBAC:EC:EMC:DEC (60:15:5:20 wt) electrolyte. 
The solvent mixture F3 = TBAC:EC:EMC:PC (60:15:5:20 wt) was investigated in combination with LiTFSI. However, as expected from the literature, the combination of PC and LiTFSI is not compatible and it is not possible to cycle a lithium-ion cell with this electrolyte [31].

\subsection{TBAC Solvent-Mixtures with $\mathrm{LiBF}_{4}$}

A total of1 $\mathrm{M} \mathrm{LiBF}_{4}$ was investigated in TBAC:EC:EMC (80:15:5 wt). However, $\mathrm{LiBF}_{4}$ did not dissolve. It was not possible to cycle the electrolyte formulation in a graphite/NCM cell. We assume that TBAC is incompatible with $\mathrm{LiBF}_{4}$.

\subsection{TBAC Solvent-Mixtures with LiFSI}

The results for the electrolytes with LiFSI as conducting salt are comparable to LiTFSI. Graphite/NCM cells with 1 M LiFSI dissolved in F2 showed a coloumbic efficiency of about $\eta_{\text {coul }}=98 \%$. The results of the cycling tests are shown in Figure 5 with three formation cycles at $C / 10$ and 100 cycles at $C / 4$.

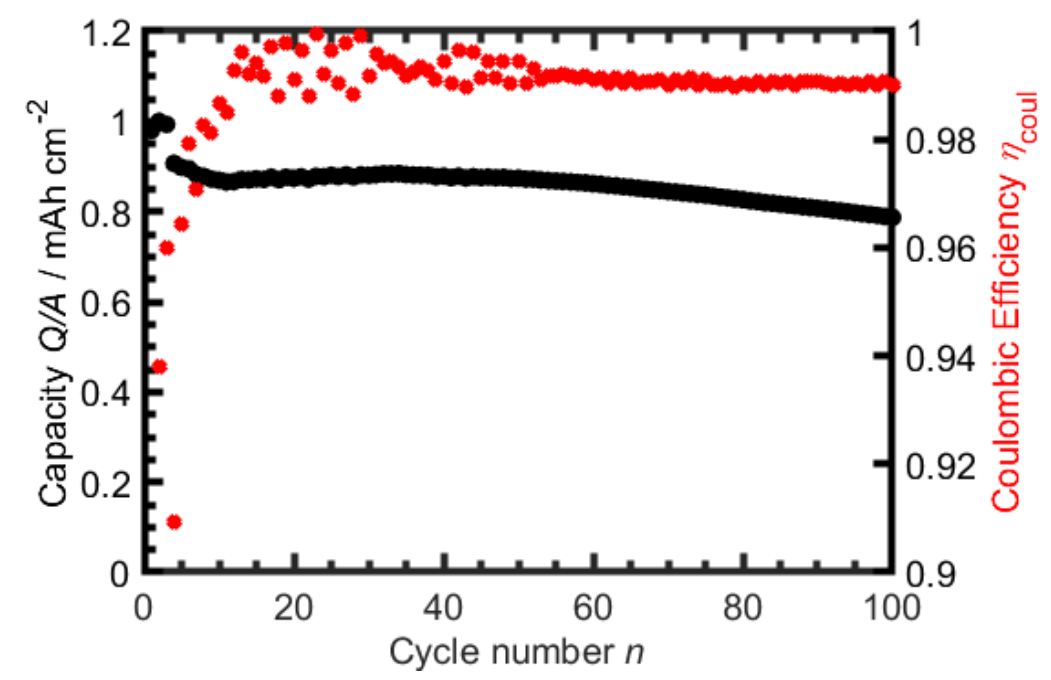

Figure 5. Cycling performance of a graphite/NCM cell with 1 M LiFSI in TBAC:EC:EMC (80:15:5 wt) electrolyte at $T=25^{\circ} \mathrm{C}$. The cell was charged and discharged at $\mathrm{C}$-rate $\mathrm{C} / 4$.

However, it was not possible to achieve a durable coulombic efficiency above $\eta_{\text {coul }}=99 \%$. Therefore TBAC-LiFSI electrolytes were not further investigated.

\subsection{TBAC Solvent-Mixtures with $\mathrm{LiPF}_{6}$}

Similar to LiTFSI and LiFSI, the conducting salt $\mathrm{LiPF}_{6}$ does dissolve in F2. The coulombic efficiency of $1 \mathrm{M} \mathrm{LiPF}_{6}$ in $\mathrm{F} 2$ in a graphite/NCM cell was about $\eta_{\text {coul }}=98 \%$. It was necessary to add DEC or PC to improve the ionic conductivity to cycle cells at C-rate C/4. Figure 6 shows the cycling results for a graphite/NCM cell with $1 \mathrm{M} \mathrm{LiPF}_{6}$ in $\mathrm{F} 4$ at $T=25^{\circ} \mathrm{C}$ with $\mathrm{C}$-rate of $\mathrm{C} / 4$. The results of the electrolyte formulation with PC (F3) are comparable to the DEC electrolyte. Therefore, we will discuss only the DEC containing electrolyte..

The coulombic efficiency after 100 cycles is above $\eta_{\text {coul }}=99.5 \%$, the remaining capacity is about $93 \%$ of the initial capacity. Compared to TBAC-LiTFSI electrolytes, the coulombic efficiency and the remaining total capacity are increased. 


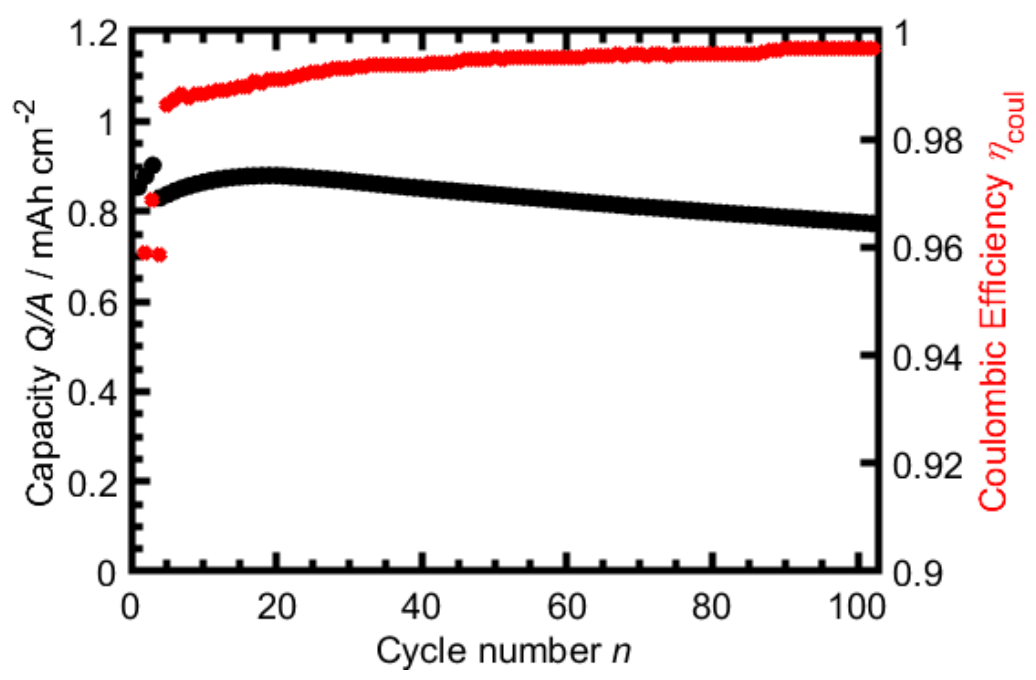

Figure 6. Cycling performance of a graphite/NCM cell with $1 \mathrm{M} \mathrm{LiPF}_{6}$ in TBAC:EC:EMC:DEC (60:15:5:20 wt) electrolyte at $T=25^{\circ} \mathrm{C}$. The cell was charged and discharged at $\mathrm{C}$-rate $\mathrm{C} / 4$.

\subsection{Cyclic Voltammetry}

To determine the electrochemical stability window, CV measurements between electrochemical inert stainless steel electrodes were observed. Figure 7a shows the electrochemical stability window of LP40 electrolyte as reference. Therefore, the potential of a stainless steel working electrode connected to the electrolyte LP40 against stainless steel was scanned at $1 \mathrm{mVs}^{-1}$. The electrolyte is stable up to $3.5 \mathrm{~V}$ vs. stainless steel.

The stability window of $\mathrm{LiPF}_{6}$ dissolved in TBAC:EC:EMC:DEC (60:15:5:20 wt) is shown in Figure $7 \mathrm{~b}$. For the second cycle, the TBAC based electrolyte seems to be stable over the total potential range. Compared to the LP40 reference electrolyte the stability is improved. At $3.5 \mathrm{~V}$ vs. stainless steel, the current begins to rise but is still below $3 \mu \mathrm{A} / \mathrm{cm}^{2}$.

Figure 7c shows the electrochemical stability window for LiTFSI dissolved in TBAC:EC:EMC:DEC (60:15:5:20 wt) between two stainless steel electrodes and Figure 7d between aluminum as working electrode and stainless steel as the counter electrode. Between two stainless steel electrodes, the stability window of the LiTFSI-TBAC based electrolyte is comparable to the LP40 reference. The electrolyte decomposes above $3.5 \mathrm{~V}$ vs. stainless steel. However, after the second cycle the decomposition current is still below $4 \mu \mathrm{A} / \mathrm{cm}^{2}$.

Since aluminum is used as a current collector in commercial lithium-ion cells the electrochemical stability window was investigated for an aluminum working electrode. CV measurements with LP40 and $\mathrm{LiPF}_{6}-\mathrm{TBAC}$ based electrolytes in contact with aluminum were comparable to $\mathrm{CV}$ measurements without aluminum. Figure $7 \mathrm{~d}$ shows the result for the LiTFSI-TBAC based electrolyte in contact with aluminum. Above $3 \mathrm{~V}$ vs. stainless steel, the decomposition current is increased by an order of one magnitude compared to the sample without aluminum. This effect is described in the literature as aluminum corrosion by the LiTFSI conducting salt $[32,33]$.

LiFSI-TBAC based electrolytes were not further investigated since the tendency to allow aluminum current collector corrosion beyond $3.8 \mathrm{~V} \mathrm{vs.} \mathrm{Li}^{+} / \mathrm{Li}^{0}$ is also described in literature [34]. 

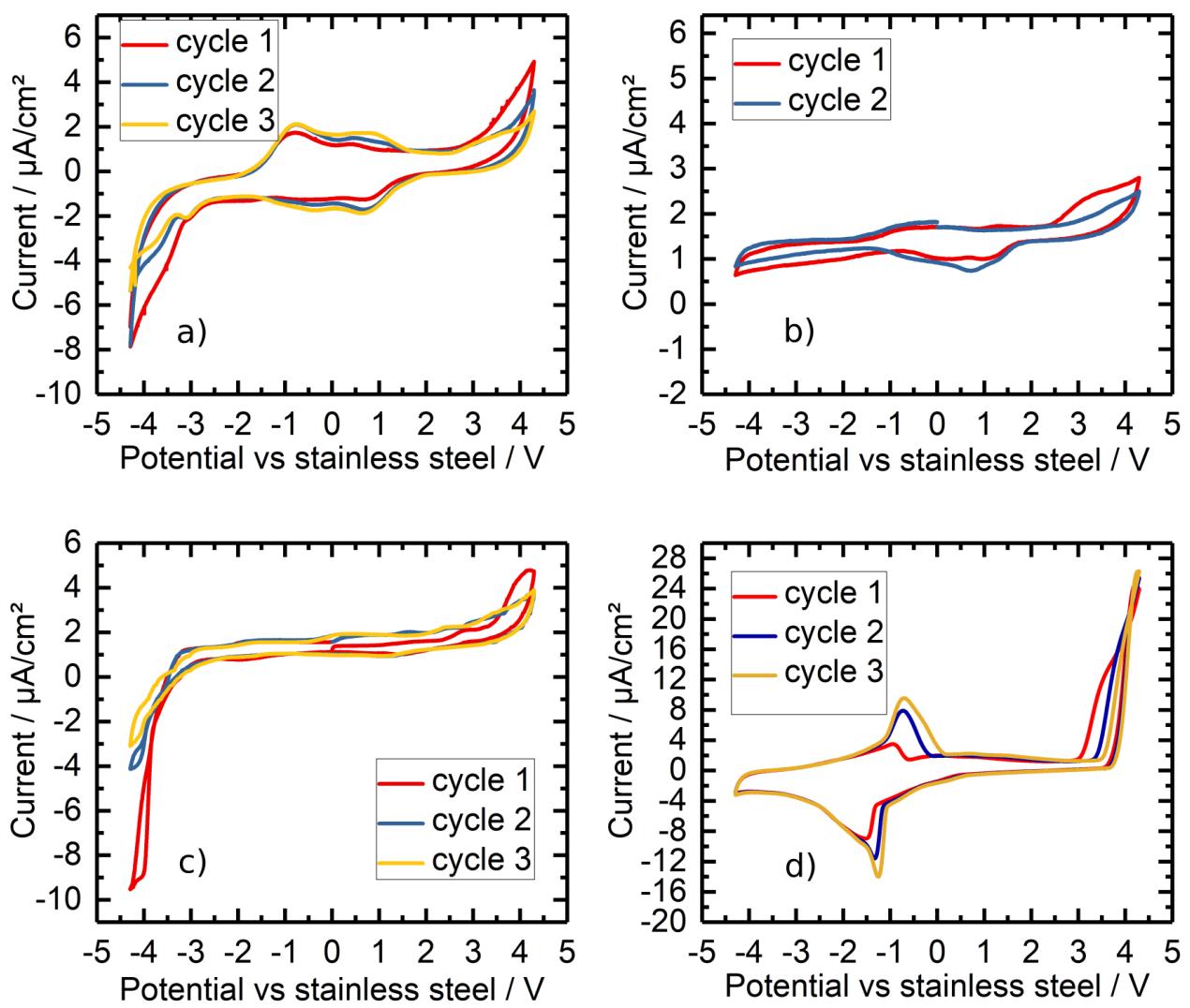

Figure 7. Electrochemical stability window of (a) LP40, (b) $1 \mathrm{M} \mathrm{LiPF}_{6}$ dissolved in TBAC:EC:EMC: DEC (60:15:5:20 wt), (c) 1 M LiTFSI in TBAC:EC:EMC:DEC (60:15:5:20 wt) (all with stainless steel as working and counter electrodes), and (d) 1 M LiTFSI in TBAC:EC:EMC:DEC (60:15:5:20 wt) (with aluminum as working electrode). Scan rate $1 \mathrm{mVs}^{-1}$. The electrochemical stability of $\mathrm{LiPF}_{6}$ in $\mathrm{TBAC}$ seems to be improved compared to LP40. LiTFSI-TBAC based electrolytes in contact with aluminum show higher decomposition rates, which is assumed to be linked to aluminum corrosion by LiTFSI.

\section{Discussion}

TBAC in combination with EC and EMC dissolves the conducting salts LiTFSI, LiFSI, and $\mathrm{LiPF}_{6}$. The main focus of this study lays in the combination of TBAC with LiTFSI to create an electrolyte with high thermal stability and high flash point, since the thermal stability and the ionic conductivity of LiTFSI are improved compared to $\mathrm{LiPF}_{6}$. By dissolving 1 M LiTFSI in TBAC:EC:EMC:DEC (60:15:5:20 wt) a coulombic efficiency of $99 \%$ at a C-rate of $C / 4$ was achieved. However, the coulombic efficiency of LiTFSI in life cycle tests was slightly reduced compared to $\mathrm{LiPF}_{6}$. To determine the reason for the efficiency reduction $\mathrm{CV}$ measurements were performed. They showed that the electrochemical stability window of $\mathrm{LiPF}_{6}-\mathrm{TBAC}$ based electrolytes is improved compared to the LP40 reference. Furthermore, the electrochemical stability window of LiTFSI-TBAC based electrolyte between stainless steel is comparable to LP40. CV measurements of the LiTFSI-TBAC based electrolyte connected to an aluminum working electrode show decomposition reactions beyond $3.5 \mathrm{~V}$ vs. stainless steel. In literature this is referred to as aluminum corrosion by LiTFSI.

TBAC itself seems to be electrochemically stable in the same window as LP40.

\section{Conclusions}

In this paper we have investigated tributyl acetylcitrate as a novel and ecofriendly electrolyte-solvent for lithium-ion cells. Compared to conventional solvents, the flash point and the boiling point are almost $200 \mathrm{~K}$ higher than that of EMC or DEC. The melting point is more than $100 \mathrm{~K}$ lower than that of EC. In combination with $\mathrm{LiPF}_{6}$ and other solvents (TBAC:EC:EMC:DEC, 60:15:5:20 wt), TBAC shows good electrochemical stability between $-4 \mathrm{~V}$ and $3 \mathrm{~V}$ vs. stainless steel. In graphite/NCM cells the coulombic efficiency is above 
$\eta_{\text {coul }}=99 \%$. After 100 cycles the remaining capacity is still above $90 \%$. Therefore, TBAC when compared to other solvents is a promising alternative to improve the intrinsic thermal stability of lithium-ion cells.

Author Contributions: Conceptualization, M.S. and K.P.B.; methodology, M.S. L.K., and K.P.B.; investigation, M.S. and L.K.; writing —original draft preparation, M.S.; writing—review and editing, L.K. and K.P.B.; visualization, M.S. and L.K.; supervision, K.P.B.; project administration, M.S.; funding acquisition, K.P.B. All authors have read and agreed to the published version of the manuscript.

Funding: This research was funded by the Bundesministerium fuer Bildung und Forschung within the BCT—Battery Cell Technology project (03XP0109H).

Institutional Review Board Statement: Not Applicable.

Informed Consent Statement: Not Applicable.

Data Availability Statement: Not Applicable.

Acknowledgments: The authors thank Münster Electrochemical Energy Technology for providing the NCM622 electrode material and Varta AG for providing the graphite electrode material.

Conflicts of Interest: The authors declare no conflict of interest. The funders had no role in the design of the study; in the collection, analyses, or interpretation of data; in the writing of the manuscript, or in the decision to publish the results.

\section{References}

1. $\mathrm{Xu}, \mathrm{K}$. Nonaqueous liquid electrolytes for lithium-based rechargeable batteries. Chem. Rev. 2004, 104, 4303-4418. [CrossRef]

2. $\mathrm{Xu}, \mathrm{K}$. Electrolytes and interphases in Li-ion batteries and beyond. Chem. Rev. 2014, 114, 11503-11618. [CrossRef] [PubMed]

3. Dimethyl Carbonate, CAS Number 616-38-6; MERCK KGaA: Darmstadt, Germany, 2020.

4. Ethyl Methyl Carbonate, CAS Number 623-53-0; MERCK KGaA: Darmstadt, Germany, 2020.

5. Diethyl Carbonate, CAS Number 105-58-8; MERCK KGaA: Darmstadt, Germany, 2020.

6. Hofmann, A.; Hanemann, T. Novel electrolyte mixtures based on dimethyl sulfone, ethylene carbonate and LiPF6 for lithium-ion batteries. J. Power Sources 2015, 298, 322-330. [CrossRef]

7. Hess, S.; Wohlfahrt-Mehrens, M.; Wachtler, M. Flammability of Li-ion battery electrolytes: flash point and self-extinguishing time measurements. J. Electrochem. Soc. 2015, 162, A3084. [CrossRef]

8. Lisbona, D.; Snee, T. A review of hazards associated with primary lithium and lithium-ion batteries. Process. Saf. Environ. Prot. 2011, 89, 434-442. [CrossRef]

9. Lei, B.; Zhao, W.; Ziebert, C.; Uhlmann, N.; Rohde, M.; Seifert, H.J. Experimental analysis of thermal runaway in 18650 cylindrical Li-ion cells using an accelerating rate calorimeter. Batteries 2017, 3, 14. [CrossRef]

10. Hammami, A.; Raymond, N.; Armand, M. Runaway risk of forming toxic compounds. Nature 2003, 424, 635-636. [CrossRef]

11. Larsson, F. Assessment of Safety Characteristics for Li-Ion Battery Cells by Abuse Testing; Dempartment of Applied Physics, Chalmers University of Technology: Gothenborg, Sweden, 2014; p. 94.

12. Larsson, F.; Andersson, P.; Blomqvist, P.; Lorén, A.; Mellander, B.E. Characteristics of lithium-ion batteries during fire tests. J. Power Sources 2014, 271, 414-420. [CrossRef]

13. Xu, K.; Ding, M.S.; Zhang, S.; Allen, J.L.; Jow, T.R. Evaluation of fluorinated alkyl phosphates as flame retardants in electrolytes for Li-ion batteries: I. Physical and electrochemical properties. J. Electrochem. Soc. 2003, 150, A161. [CrossRef]

14. Dalavi, S.; Xu, M.; Ravdel, B.; Zhou, L.; Lucht, B.L. Nonflammable electrolytes for lithium-ion batteries containing dimethyl methylphosphonate. J. Electrochem. Soc. 2010, 157, A1113. [CrossRef]

15. Kalhoff, J.; Eshetu, G.G.; Bresser, D.; Passerini, S. Safer electrolytes for lithium-ion batteries: state of the art and perspectives. ChemSusChem 2015, 8, 2154-2175. [CrossRef]

16. Kim, G.; Jeong, S.; Joost, M.; Rocca, E.; Winter, M.; Passerini, S.; Balducci, A. Use of natural binders and ionic liquid electrolytes for greener and safer lithium-ion batteries. J. Power Sources 2011, 196, 2187-2194. [CrossRef]

17. Lux, S.F.; Schmuck, M.; Jeong, S.; Passerini, S.; Winter, M.; Balducci, A. Li-ion anodes in air-stable and hydrophobic ionic liquid-based electrolyte for safer and greener batteries. Int. J. Energy Res. 2010, 34, 97-106. [CrossRef]

18. Tsurumaki, A.; Agostini, M.; Poiana, R.; Lombardo, L.; Lufrano, E.; Simari, C.; Matic, A.; Nicotera, I.; Panero, S.; Navarra, M.A. Enhanced safety and galvanostatic performance of high voltage lithium batteries by using ionic liquids. Electrochim. Acta 2019, 316, 1-7. [CrossRef]

19. Navarra, M.A. Ionic liquids as safe electrolyte components for Li-metal and Li-ion batteries. MRS Bull. 2013, 38, 548. [CrossRef]

20. Adiponitrile, CAS Number 111-69-3; MERCK KGaA: Darmstadt, Germany, 2020.

21. Isken, P.; Dippel, C.; Schmitz, R.; Schmitz, R.; Kunze, M.; Passerini, S.; Winter, M.; Lex-Balducci, A. High flash point electrolyte for use in lithium-ion batteries. Electrochim. Acta 2011, 56, 7530-7535. [CrossRef] 
22. Sun, X.G.; Angell, C.A. New sulfone electrolytes for rechargeable lithium batteries.: Part I. Oligoether-containing sulfones. Electrochem. Commun. 2005, 7, 261-266. [CrossRef]

23. Xu, K.; Angell, C.A. Sulfone-based electrolytes for lithium-ion batteries. J. Electrochem. Soc. 2002, 149, A920. [CrossRef]

24. Tributyl Acetylcitrat, CAS Number 77-90-7; MERCK KGaA: Darmstadt, Germany, 2020.

25. Bae, J.W.; Yeo, M.; Shin, E.J.; Park, W.H.; Lee, J.E.; Nam, B.U.; Kim, S.Y. Eco-friendly plasticized poly (vinyl chloride)-acetyl tributyl citrate gels for varifocal lens. RSC Adv. 2015, 5, 94919-94925. [CrossRef]

26. Johnson, W., Jr. Final report on the safety assessment of acetyl triethyl citrate, acetyl tributyl citrate, acetyl trihexyl citrate, and acetyl trioctyl citrate. Int. J. Toxicol. 2002, 21, 1-17.

27. Renard C. Tributyl Acetylcitrat as Component of Nail Polish. U.S. Patent 20040170584A1, 2 September 2004.

28. Ethylcarbonate, CAS Number 96-49-1; MERCK KGaA: Darmstadt, Germany, 2021.

29. Propylencarbonate, CAS Number 108-32-7; MERCK KGaA: Darmstadt, Germany, 2021.

30. Dahbi, M.; Ghamouss, F.; Tran-Van, F.; Lemordant, D.; Anouti, M. Comparative study of EC/DMC LiTFSI and LiPF6 electrolytes for electrochemical storage. J. Power Sources 2011, 196, 9743-9750. [CrossRef]

31. Pan, Y.; Wang, G.; Lucht, B.L. Cycling performance and surface analysis of Lithium bis (trifluoromethanesulfonyl) imide in propylene carbonate with graphite. Electrochim. Acta 2016, 217, 269-273. [CrossRef]

32. Krämer, E.; Schedlbauer, T.; Hoffmann, B.; Terborg, L.; Nowak, S.; Gores, H.J.; Passerini, S.; Winter, M. Mechanism of anodic dissolution of the aluminum current collector in 1 M LiTFSI EC: DEC 3: 7 in rechargeable lithium batteries. J. Electrochem. Soc. 2012, 160, A356. [CrossRef]

33. Morita, M.; Shibata, T.; Yoshimoto, N.; Ishikawa, M. Anodic behavior of aluminum current collector in LiTFSI solutions with different solvent compositions. J. Power Sources 2003, 119, 784-788. [CrossRef]

34. Abouimrane, A.; Ding, J.; Davidson, I. Liquid electrolyte based on lithium bis-fluorosulfonyl imide salt: Aluminum corrosion studies and lithium ion battery investigations. J. Power Sources 2009, 189, 693-696. [CrossRef] 